\title{
Lysobacter soli sp. nov., isolated from soil of a ginseng field
}

\author{
Sathiyaraj Srinivasan, ${ }^{1}$ Myung Kyum Kim, ${ }^{1,2}$ Gayathri Sathiyaraj, ${ }^{1}$ \\ Ho-Bin Kim, ${ }^{1}$ Yeon-Ju Kim ${ }^{1}$ and Deok-Chun Yang ${ }^{1}$
}

Correspondence

Deok-Chun Yang dcyang@khu.ac.kr

\author{
${ }^{1}$ Korean Ginseng Center and Ginseng Genetic Resource Bank, Kyung Hee University, 1 Seocheon- \\ dong, Giheung-gu Yongin-si, Gyeonggi-do 449-701, Republic of Korea \\ ${ }^{2}$ Department of Bio and Environmental Technology, Division of Environmental and Life Science, \\ College of Natural Science, Seoul Women's University, Seoul 139-774, Republic of Korea
}

\begin{abstract}
Strain DCY $21^{\top}$, a Gram-negative, gliding and rod-shaped aerobic bacterium was isolated from soil of a ginseng field in the Republic of Korea and characterized using a polyphasic approach in order to determine its taxonomic position. Comparative 16S rRNA gene sequence analysis revealed that strain DCY $21^{\top}$ clustered with the species of the genus $L y s o b a c t e r$. It was closely related to Lysobacter gummosus LMG $8763^{\top}$ (97.9\%), Lysobacter capsici YC5194 ${ }^{\top}(97.6 \%)$, Lysobacter antibioticus DSM $2044^{\top}(97.5 \%)$, Lysobacter niastensis DSM $18481^{\top}(97.2 \%)$ and Lysobacter enzymogenes DSM $2043^{\top}(96.9 \%)$. The major cellular fatty acids of strain DCY $21^{\top}$ were iso- $\mathrm{C}_{15: 0}(34.3 \%)$, iso- $\mathrm{C}_{17: 1} \omega 9 c(19.5 \%)$ and iso- $\mathrm{C}_{17: 0}(17.2 \%)$ and the major isoprenoid quinone was $\mathrm{Q}-8$. The major polar lipids of strain $\mathrm{DCY} 21^{\top}$ were diphosphatidylglycerol, phosphatidylethanolamine, phosphatidylglycerol and phosphatidyl- $N$ methylethanolamine. The $\mathrm{G}+\mathrm{C}$ content of the total DNA was $65.4 \mathrm{~mol} \%$. The DNA-DNA relatedness values, and biochemical and physiological characteristics strongly supported the genotypic and phenotypic differentiation of strain DCY $21^{\top}$ from species of the genus Lysobacter. Strain DCY $21^{\top}$ therefore represents a novel species, for which the name Lysobacter soli sp. nov. is proposed. The type strain is DCY $21^{\top}\left(=\right.$ KCTC $22011^{\top}=$ LMG $\left.24126^{\top}\right)$.
\end{abstract}

The genus Lysobacter, in the class Gammaproteobacteria and family Xanthomonadaceae, was first described by Christensen \& Cook (1978) based on the non-fruiting, gliding nature of bacteria with high DNA G $+C$ contents. At the time of writing, the genus Lysobacter consists of 16 species with validly published names. Recently, three novel species of the genus, Lysobacter panaciterrae Gsoil $068^{\mathrm{T}}$ from the rhizosphere soil of a ginseng plant (Ten et al., 2009), Lysobacter ximonensis XM $415^{\mathrm{T}}$ (Wang et al., 2009) from the soil of Tibet and Lysobacter oryzae $\mathrm{YC} 269^{\mathrm{T}}$ from the rhizosphere of a rice plant (Aslam et al., 2009) have been described.

Strain DCY $21^{\mathrm{T}}$ was originally isolated from the soil of a ginseng field near Daejeon city in the Republic of Korea and characterized by a polyphasic approach. DCY $21^{\mathrm{T}}$ was one of the isolates dominating a 10 -fold diluted sample on an R2A agar plate incubated under aerobic conditions. The

The GenBank/EMBL/DDBJ accession number for the $16 \mathrm{~S}$ rRNA gene sequence of strain DCY $21^{\top}$ is EF623862.

Two-dimensional thin-layer chromatograms of polar lipids of strain DCY $21^{\top}$, cellular fatty acid profiles and DNA-DNA relatedness data for strain DCY $21^{\top}$ and closely related type strains of the genus Lysobacter are available with the online version of this paper. strain was routinely cultured on R2A agar (Difco) at $30{ }^{\circ} \mathrm{C}$ and maintained as a glycerol suspension $(20 \%, w / v)$ at $-70{ }^{\circ} \mathrm{C}$. In this study, strain DCY $21^{\mathrm{T}}$ was characterized by a polyphasic approach, including phylogenetic analysis based on 16S rRNA gene sequences, genomic DNA relatedness and chemotaxonomic and phenotypic properties. On the basis of the results obtained in this study, we propose that strain DCY $21^{\mathrm{T}}$ should be placed in the genus Lysobacter as the type strain of a novel species, namely Lysobacter soli.

The Gram reaction was performed via the non-staining method as described by Buck (1982). Cell morphology and motility were observed under a Nikon light microscope ( $\times 1000$ magnification) using the hanging drop method, with cells grown on R2A agar (Difco) for 2 days at $30{ }^{\circ} \mathrm{C}$. Catalase activity was determined with $3 \%(\mathrm{v} / \mathrm{v}) \mathrm{H}_{2} \mathrm{O}_{2}$, and oxidase activity was determined using $1 \%(\mathrm{w} / \mathrm{v})$ tetramethyl $p$-phenylenediamine. Growth at different temperatures $\left(4,25,30,37,42\right.$ and $45{ }^{\circ} \mathrm{C}$ ) and at $\mathrm{pH} 5.0-11.0$ (at intervals of $0.5 \mathrm{pH}$ units) was assessed after 5 days of incubation on LB agar (Difco). Growth on nutrient agar, trypticase soy agar (TSA, Difco), and LB agar was also evaluated at $30^{\circ} \mathrm{C}$. Anaerobic growth was assessed in serum bottles by adding a thioglycolate $\left(1 \mathrm{~g} \mathrm{l}^{-1}\right)$ to the 
R2A broth and substituting the upper air layer with nitrogen gas. Substrate utilization as the sole carbon source and some enzyme activities were tested by using the API ZYM, API $50 \mathrm{CH}$, API $20 \mathrm{NE}$ and API $32 \mathrm{GN}$ galleries according to the instructions of the manufacturer (bioMérieux).

Isoprenoid quinones were extracted with chloroform/ methanol $(2: 1, \mathrm{v} / \mathrm{v})$, purified by TLC and subsequently analysed by HPLC, as previously described by Collins \& Jones (1981) and Shin et al. (1996). For fatty acid methyl ester analysis, cells were allowed to grow on TSA for $48 \mathrm{~h}$ at $30{ }^{\circ} \mathrm{C}$, and then two-loops full of well-grown cells were harvested. Fatty acid methyl esters were prepared, separated and identified by using the Sherlock Microbial Identification System (MIDI; Sasser, 1990). Polar lipids were extracted and examined by the two-dimensional TLC technique (Minnikin et al., 1977).

Extraction of genomic DNA was performed by using a commercial genomic DNA extraction kit (SolGent), and PCR-mediated amplification of the 16S rRNA gene and sequencing of the purified PCR product were carried out according to Kim et al. (2005). Sequences of the 16S rRNA gene were compiled by using SeqMan software (DNASTAR). The 16S rRNA gene sequences of related taxa were obtained from GenBank. Multiple alignments were performed by using the CLUSTAL x program (Thompson et al., 1997). Gaps were edited out with the BioEdit program (Hall, 1999). Evolutionary distances were calculated by using the Kimura two-parameter model (Kimura, 1983). Phylogenetic trees were reconstructed by the neighbourjoining (Saitou \& Nei, 1987) and maximum-parsimony (Fitch, 1971) methods by using the MEGA3 program (Kumar et al., 2004) with bootstrap values based on 1000 replications (Felsenstein, 1985).

For measurement of $\mathrm{G}+\mathrm{C}$ content, chromosomal DNA of the novel strain was extracted and purified as described by Moore \& Dowhan (1995). The isolated DNA was enzymically degraded into nucleosides and the nucleosides were analysed by using HPLC as described by Tamaoka \& Komagata (1984) and Mesbah et al. (1989). DNA-DNA hybridization was performed fluorometrically, according to the method developed by Ezaki et al. (1989), using photobiotin-labelled DNA probes and micro-dilution wells. Five replications were conducted for each sample. The highest and lowest values obtained for each sample were excluded and the remaining three values were used for the calculation of hybridization values. The DNA relatedness values quoted are expressed as means of these three values.

Cells of strain DCY $21^{\mathrm{T}}$ were Gram-negative, non-sporeforming, gliding, aerobic rods, $0.2-0.5 \mu \mathrm{m}$ wide and 0.6$0.9 \mu \mathrm{m}$ long. The strain grew well at $30{ }^{\circ} \mathrm{C}$, and growth occurred at $42{ }^{\circ} \mathrm{C}$. Phenotypic, biochemical and chemotaxonomic characteristics that differentiate strain DCY $21^{\mathrm{T}}$ from other related species of the genus Lysobacter are listed in Table 1. The major fatty acids detected (percentages of the total cellular fatty acids) from strain $\mathrm{DCY} 21^{\mathrm{T}}$ were iso$\mathrm{C}_{15: 0}(34.3 \%)$, iso- $\mathrm{C}_{17: 1} \omega 9 \mathrm{c}(19.5 \%)$ and iso- $\mathrm{C}_{17: 0}$ $(17.2 \%)$. Although the major fatty acids were similar to those of other members of the genus Lysobacter, the presence of 10-methyl $C_{16: 0}$ differentiated this strain from other members of the genus. A comparison of fatty acid profiles among Lysobacter species is shown in Supplementary Table S1 (available in IJSEM Online). The major ubiquinone detected was Q-8. This quinone system is a characteristic feature of members of the genus Lysobacter (Bae et al., 2005).

Strain DCY $21^{\mathrm{T}}$ exhibited a polar lipid profile that was almost identical with those of other species of the genus Lysobacter (Park et al., 2008), containing predominantly diphosphatidylglycerol, phosphatidylethanolamine, phosphatidylglycerol, phosphatidyl- $N$-methylethanolamine and a minor amount of an unknown aminolipid (Supplementary Fig. S1).

The 16S rRNA gene sequence of strain DCY $21^{\mathrm{T}}$ determined in this study was a continuous stretch of $1496 \mathrm{bp}$. The phylogenetic tree (Fig. 1) shows that strain $\mathrm{DCY} 21^{\mathrm{T}}$ clustered within the genus Lysobacter of the class Gammaproteobacteria. The $16 \mathrm{~S}$ rRNA gene sequence of strain DCY $21^{\mathrm{T}}$ showed high similarity with Lysobacter gummosus LMG $8763^{\mathrm{T}}(97.9 \%)$, Lysobacter capsici YC5194 $^{\mathrm{T}}(97.6 \%)$, Lysobacter antibioticus DSM $2044^{\mathrm{T}}$ (97.5\%), Lysobacter niastensis DSM $18481^{\mathrm{T}}(97.2 \%)$ and Lysobacter enzymogenes DSM $2043^{\mathrm{T}}(96.9 \%)$. The DNA $\mathrm{G}+\mathrm{C}$ content of strain DCY $21^{\mathrm{T}}$ was $65.4 \mathrm{~mol} \%$. DNADNA hybridization was performed to differentiate strain DCY $21^{\mathrm{T}}$ from the closely related species of the genus Lysobacter. Strain DCY $21^{\mathrm{T}}$ exhibited relatively low levels of DNA-DNA relatedness (Supplementary Table S2) with respect to $L$. gummosus (35\%), L. capsici $(45 \%), L$. antibioticus (53\%), L. enzymogenes ( $25 \%)$ and L. niastensis $(28 \%)$, indicating that they are not related at the species level (Wayne et al., 1987). These data indicate that strain DCY $21^{\mathrm{T}}$ is clearly separated from other members of the genus Lysobacter.

As shown in Table 1 and Supplementary Table S1, the phenotypic and chemotaxonomic characteristics of strain DCY $21^{\mathrm{T}}$ are enough to differentiate it from those species of the genus Lysobacter that form a consistent phylogenetic cluster (except L. niastensis, which forms polyphyletic relationships with other species). Therefore, on the basis of the data presented, strain DCY $21^{\mathrm{T}}$ clearly represents a novel member of the genus Lysobacter, for which the name Lysobacter soli sp. nov. is proposed.

\section{Description of Lysobacter soli sp. nov.}

Lysobacter soli (so'li. L. neut. gen. n. soli of soil, the source of the organism).

Cells are Gram-negative, aerobic, gliding and rod-shaped, approximately $0.2-0.5 \mu \mathrm{m}$ wide and $0.6-0.9 \mu \mathrm{m}$ long. Colonies grown on R2A agar (Difco) for 2 days are 
Table 1. Differential characteristics of strain $D C Y 21^{\top}$ and closely related species of the genus Lysobacter

Strains: 1, Lysobacter soli DCY $21^{\mathrm{T}}$ sp. nov.; 2, L. antibioticus DSM 2044 ${ }^{\mathrm{T}}$; 3, L. capsici YC5194 ${ }^{\mathrm{T}}$; 4, L. enzymogenes DSM 2043 ${ }^{\mathrm{T}}$; 5, L. gummosus LMG $8763^{\mathrm{T}}$; 6, L. niastensis DSM $18481^{\mathrm{T}}$. + , Positive; -, negative; $\mathrm{W}$, weakly positive; C, cream; DY, deep yellow; LB, light beige; PY, pale yellow, Y, yellow; YC, yellow-cream.

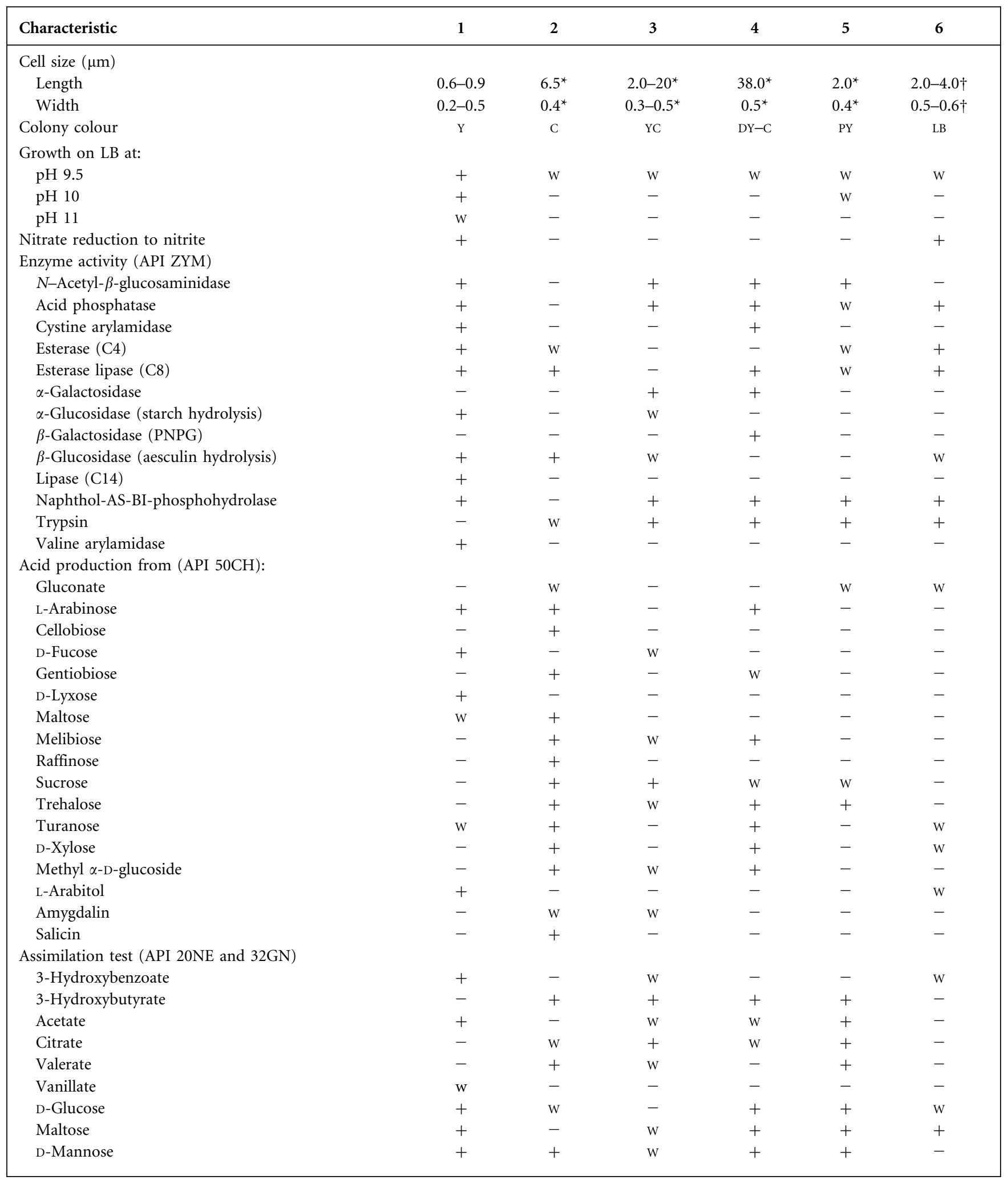


Table 1. cont.

\begin{tabular}{|c|c|c|c|c|c|c|}
\hline Characteristic & 1 & 2 & 3 & 4 & 5 & 6 \\
\hline Melibiose & - & - & - & + & + & - \\
\hline Sucrose & - & $\mathrm{w}$ & - & $\mathrm{w}$ & - & - \\
\hline myo-Inositol & $\mathrm{w}$ & - & $\mathrm{w}$ & - & - & - \\
\hline L-Histidine & - & - & $\mathrm{w}$ & - & + & + \\
\hline Salicin & - & - & $\mathrm{w}$ & + & - & - \\
\hline Glycogen & - & + & $\mathrm{w}$ & + & + & - \\
\hline DNA G $+\mathrm{C}$ content $(\mathrm{mol} \%)$ & 65.4 & $69.2^{\star}$ & $65.4^{\star}$ & $69.0^{*}$ & $65.7^{\star}$ & $66.6 \dagger$ \\
\hline
\end{tabular}

Data from other studies as indicated: ${ }^{\star}$ Park et al. (2008); †Weon et al. (2007).

convex, glistening, circular and yellow. The temperature range for growth is $4-42{ }^{\circ} \mathrm{C}$, but the optimum temperature is $30{ }^{\circ} \mathrm{C}$; no growth is observed at $45{ }^{\circ} \mathrm{C}$. The $\mathrm{pH}$ range for growth is 5-10.5; weak growth is observed at $\mathrm{pH} 11$ and optimum growth at $\mathrm{pH} 7.0-7.5$. Oxidase and catalasepositive. Reduction of nitrates to nitrites and glucose acidification are positive; indole production is negative. The following carbon sources are utilized in the API 20NE and API 32GN tests: acetate, $N$-acetylglucosamine, Dglucose, 3-hydroxybenzoate, 4-hydroxybenzoate, maltose, D-mannose and L-proline. Utilization of the following substrates is negative: adipate, L-arabinose, L-alanine, caprate, citrate, L-fucose, glycogen, gluconate, 3-hydroxybutyrate, L-histidine, itaconate, 2-ketogluconate, 5ketogluconate, lactate, L-malate, D-mannitol, malonate, melibiose, phenylacetate, propionate, D-ribose, salicin, Lserine, D-sorbitol, suberate, sucrose and valerate. In assays with API ZYM, $N$-acetyl- $\beta$-glucosaminidase, acid phosphatase, alkaline phosphatase, cystine arylamidase, esterase
(C4), esterase lipase (C8), $\alpha$-glucosidase, $\beta$-glucosidase, leucine arylamidase, lipase (C14), naphthol-AS-BI-phosphohydrolase and valine arylamidase activities are present, but $\alpha$-chymotrypsin, $\alpha$-fucosidase, $\alpha$-galactosidase, $\beta$ galactosidase, $\beta$-glucuronidase, $\alpha$-mannosidase and trypsin are absent. Other differential phenotypic and biochemical characteristics are summarized in Table 1. Contains predominantly diphosphatidylglycerol, phosphatidylethanolamine, phosphatidylglycerol, phosphatidyl- $N$-methylethanolamine and a minor amount of unknown aminolipid. Q-8 is the predominant quinone. The major cellular fatty acids are iso- $\mathrm{C}_{15: 0}(34.3 \%)$, iso- $\mathrm{C}_{17: 1} \omega 9 \mathrm{c}$ $(19.5 \%)$, iso- $\mathrm{C}_{17: 0}(17.2 \%)$, iso- $\mathrm{C}_{16: 0}(7.5 \%)$ and iso$\mathrm{C}_{11: 0} 3-\mathrm{OH}(5.8 \%)$. The DNA G $+\mathrm{C}$ content of the type strain is $65.4 \mathrm{~mol} \%$.

The type strain, DCY $21^{\mathrm{T}}\left(=\mathrm{KCTC} 22011^{\mathrm{T}}=\mathrm{LMG} 24126^{\mathrm{T}}\right.$ ) was isolated from soil of a ginseng field in Daejeon City, South Korea.

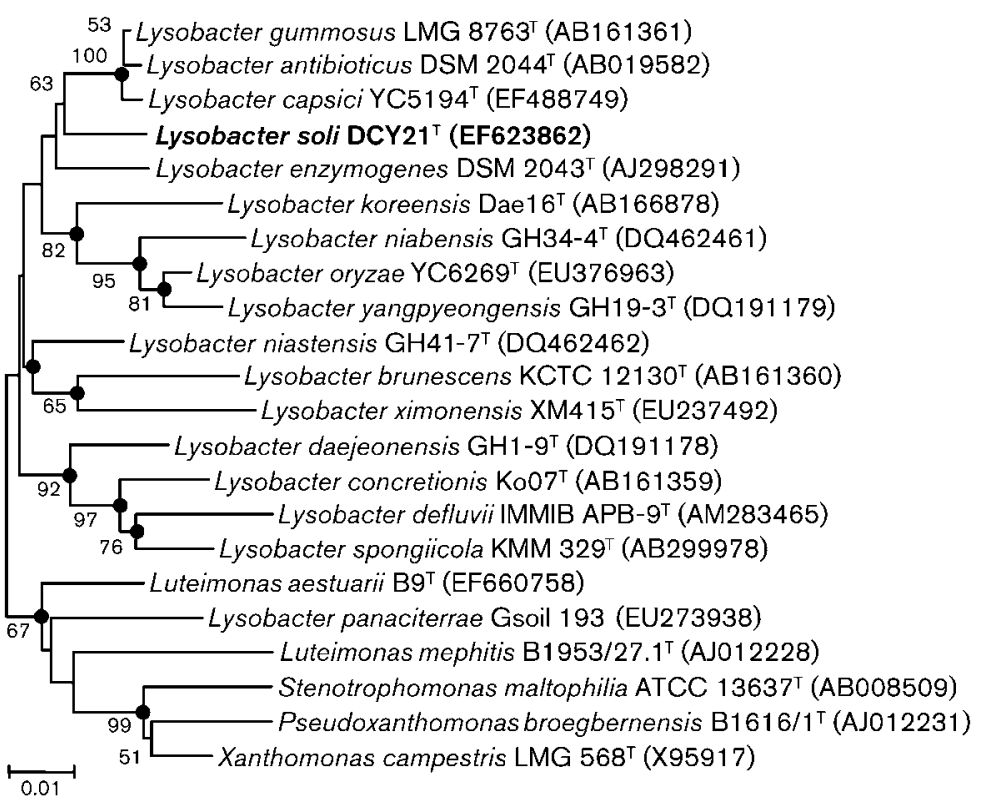

Fig. 1. Phylogenetic relationship between strain DCY $21^{\top}$ and related species of the genus Lysobacter and closely related genera. Tree reconstructed by using the neighbourjoining method. Bar, 0.01 substitutions per nucleotide position. Bootstrap values (expressed as percentages of 1000 replications) greater than $50 \%$ are shown at the branch points. Filled circles indicate generic branches that were also recovered by using maximum-parsimony algorithms. 


\section{References}

Aslam, Z., Yasir, M., Jeon, C. O. \& Chung, Y. R. (2009). Lysobacter oryzae sp. nov., isolated from the rhizosphere of rice (Oryza sativa L.). Int J Syst Evol Microbiol 59, 675-680.

Bae, H.-S., Im, W.-T. \& Lee, S.-T. (2005). Lysobacter concretionis sp. nov., isolated from anaerobic granules in an upflow anaerobic sludge blanket reactor. Int J Syst Evol Microbiol 55, 1155-1161.

Buck, J. D. (1982). Nonstaining (KOH) method for determination of Gram reactions of marine bacteria. Appl Environ Microbiol 44, 992993.

Christensen, P. \& Cook, F. D. (1978). Lysobacter, a new genus of nonfruiting, gliding bacteria with a high base ratio. Int J Syst Bacteriol 28, 367-393.

Collins, M. D. \& Jones, D. (1981). Distribution of isoprenoid quinone structural types in bacteria and their taxonomic implications. Microbiol Rev 45, 316-354.

Ezaki, T., Hashimoto, Y. \& Yabuuchi, E. (1989). Fluorometric deoxyribonucleic acid-deoxyribonucleic acid hybridization in microdilution wells as an alternative to membrane filter hybridization in which radioisotopes are used to determine genetic relatedness among bacterial strains. Int J Syst Bacteriol 39, 224-229.

Felsenstein, J. (1985). Confidence limits on phylogenies: an approach using the bootstrap. Evolution 39, 783-791.

Fitch, W. M. (1971). Toward defining the course of evolution: minimum change for a specific tree topology. Syst Zool 20, 406-416.

Hall, T. A. (1999). BioEdit: a user-friendly biological sequence alignment editor and analysis program for Windows 95/98/NT. Nucleic Acids Symp Ser 41, 95-98.

Kim, M. K., Im, W.-T., Ohta, H., Lee, M. \& Lee, S.-T. (2005). Sphingopyxis granuli sp. nov., a $\beta$-glucosidase producing bacterium in the family Sphingomonadaceae in $\alpha-4$ subclass of the Proteobacteria. J Microbiol 43, 152-157.

Kimura, M. (1983). The Neutral Theory of Molecular Evolution. Cambridge: Cambridge University Press.

Kumar, S., Tamura, K. \& Nei, M. (2004). MEGA3: integrated software for molecular evolutionary genetics analysis and sequence alignment. Brief Bioinform 5, 150-163.

Mesbah, M., Premachandran, U. \& Whitman, W. B. (1989). Precise measurement of the $\mathrm{G}+\mathrm{C}$ content of deoxyribonucleic acid by highperformance liquid chromatography. Int J Syst Bacteriol 39, 159-167.
Minnikin, D. E., Patel, P. V., Alshamaony, L. \& Goodfellow, M. (1977). Polar lipid composition in the classification of Nocardia and related bacteria. Int J Syst Bacteriol 27, 104-117.

Moore, D. D. \& Dowhan, D. (1995). Preparation and analysis of DNA. In Current Protocols in Molecular Biology, pp. 2-11. Edited by F. M. Ausubel, R. Brent, R. E. Kingston, D. D. Moore, J. G. Seidman, J. A. Smith \& K. Struhl. New York: Wiley.

Park, J. H., Kim, R., Aslam, Z., Jeon, C. O. \& Chung, Y. R. (2008). Lysobacter capsici sp. nov., with antimicrobial activity, isolated from the rhizosphere of pepper, and emended description of the genus Lysobacter. Int J Syst Evol Microbiol 58, 387-392.

Saitou, N. \& Nei, M. (1987). The neighbor-joining method: a new method for reconstructing phylogenetic trees. Mol Biol Evol 4, 406425.

Sasser, M. (1990). Identification of bacteria by gas chromatography of cellular fatty acids, MIDI Technical Note 101. Newark, DE: MIDI Inc.

Shin, Y. K., Lee, J.-S., Chun, C. O., Kim, H.-J. \& Park, Y.-H. (1996). Isoprenoid quinone profiles of the Leclercia adecarboxylata KCTC $1036^{\mathrm{T}}$. J Microbiol Biotechnol 6, 68-69.

Tamaoka, J. \& Komagata, K. (1984). Determination of DNA base composition by reversed-phase high-performance liquid chromatography. FEMS Microbiol Lett 25, 125-128.

Ten, L. N., Jung, H.-M., Im, W.-T., Yoo, S.-A., Oh, H.-M. \& Lee, S.-T. (2009). Lysobacter panaciterrae sp. nov., isolated from soil of a ginseng field. Int J Syst Evol Microbiol 59, 958-963.

Thompson, J. D., Gibson, T. J., Plewniak, F., Jeanmougin, F. \& Higgins, D. G. (1997). The CLUSTAL_X windows interface: flexible strategies for multiple sequence alignment aided by quality analysis tools. Nucleic Acids Res 25, 4876-4882.

Wang, Y., Dai, J., Zhang, L., Luo, X., Li, Y., Chen, G., Tang, Y., Meng, Y. \& Fang, C. (2009). Lysobacter ximonensis sp. nov., isolated from soil. Int J Syst Evol Microbiol 59, 786-789.

Wayne, L. G., Brenner, D. J., Colwell, R. R., Grimont, P. A. D., Kandler, O., Krichevsky, M. I., Moore, L. H., Moore, W. E. C., Murray, R. G. E. \& other authors (1987). International Committee on Systematic Bacteriology. Report of the ad hoc committee on reconciliation of approaches to bacterial systematics. Int J Syst Bacteriol 37, 463-464.

Weon, H.-Y., Kim, B.-Y., Kim, M.-K., Yoo, S.-H., Kwon, S.-W., Go, S.-J. \& Stackebrandt, E. (2007). Lysobacter niabensis sp. nov. and Lysobacter niastensis sp. nov., isolated from greenhouse soils in Korea. Int J Syst Evol Microbiol 57, 548-551. 